will not be overlooked in any State action to relieve the miner, that such action shall not, in effect, take the form of subsidising the wasteful and airpolluting consumption of raw coal. In the long run, such action will be futile, for the natural trend is for fuel to be consumed in smokeless forms and preferably fluid, such as gas and electricity, which permit cleanliness and better control in use. This is true both in industry and the home. Already whole estates of houses are being built with provision for the use of smokeless fuel only, and there is little doubt that these examples will be followed.

One reform which a rational sales system would enforce would be to relate prices more to calorific value and less to size of coal. Present practice dates from the time when big coal usually was clean coal. Modern cleaning processes have altered this, and the high premium on size cannot be justified. There are few uses for coal in large lumps, and even the householder is demanding sized nuts and cobbles. Mechanical stokers and pulverised fuel plants can only use small fuel. To an increasing extent, collieries are having to break lump coal, and the best methods of doing this provide technical problems with which the report deals. Selling prices based on calorific value would tend to penalise only those industries which use the heat in an unthrifty manner. There is in dearer coal a dilemma for the coal trade, for higher prices will encourage more economy and therefore reduced consumption.

The Coal Survey, one of the most beneficent activities of the Board, has now been in operation so long and has collected such extensive data as to show its value increasing with time.

The Fuel Research Station has a plant, described in the report, for experimental hydrogenation of coal and tar. With the plant "it has been found that the technique of hydrogenation does not necessarily require high pressure, and thanks to increasing knowledge of catalysts, a process has been worked out on a semi-commercial scale for treating at atmospheric pressure the acids present in tar from gas works and coke ovens to obtain motor spirits".

The report refers to many other aspects of fuel problems and the reader will miss few topics of current interest.

H. J. H.

\title{
Scientific Centenaries in 1936
}

\author{
By Eng.-Capt. Edgar C. Smith, O.B.E., R.N.
}

\begin{abstract}
"r $\mathrm{HE}$ great inheritance of mathematical knowledge which the ancients bequeathed to posterity could not, on the revival of learning, be immediately taken possession of nor could even its existence be discovered, but by degrees . . . The repositories of the ancient treasures were to be opened, and made accessible; the knowledge of the languages was to be acquired; the manuscripts were to be deciphered; and the skill of the grammarian and the critic were to precede, in a certain degree, that of the geometrician or the astronomer . . . The study of the remains of antiquity gradually produced men of taste and intelligence, who were able to correct the faults of the manuscripts they copied, and to explain the difficulties of the authors they translated. Such were Purbach, Regiomontanus, Commandine, Maurolycus, and many others."
\end{abstract}

So wrote John Playfair more than a century ago in his historical sketch of the principal discoveries made in natural philosophy from the revival of learning down to the end of the eighteenth century, and he said that of the mathematicians of the fifteenth century it was Regiomontanus who held the highest rank. A review of the scientific centenaries for 1936 may therefore well begin with a note on this famous man, who was born on June 6 , 1436, five hundred years ago, and, in his short life of forty years, in various ways made the world his debtor.
The son of well-to-do parents and born in Franconia, Regiomontanus (or Johann Müller, to give him his German name) was still a youth when Gutenberg made his first metal type and the learned Greeks fled from Constantinople to Italy and elsewhere, carrying their precious manuscripts ; but he was destined to be remembered for the use he made of both those manuscripts and the printing press. His schooldays were passed at Leipzig, and later he was a pupil of Purbach's at Vienna. His abilities soon attracted attention, and through the patronage of Cardinal Bessarion he was able to visit Italy. One of the first fruits of his labours was his "De Triangulis" written in 1464, which has been called the earliest modern systematic exposition of trigonometry, plane and spherical. To him we owe the term 'sine'. From his visit to Italy he returned northward to become astronomer to Matthias Corvinus, the able king of Hungary, but a few years later he settled at Nuremberg, where with the aid of one of its wealthy citizens he set up a printing press and fitted up an observatory.

It was at Nuremberg that Regiomontanus published his "Ephemerides", a copy of which was used by Columbus. This book was the forerunner of our 
nautical almanacs. In 1475 Pope Sixtus IV made Regiomontanus bishop of Ratisbon, and called him to Rome to assist in the reformation of the calendar. He died at Rome on July 6, 1476. His fame was such that he was buried in the Pantheon, the honours paid to him at his death proving, said Playfair, "that science had now become a distinction which the great were disposed to recognise".

Just three centuries after the birth of Regiomontanus at Königsberg, Joseph Louis Lagrange, the greatest mathematician of the eighteenth century, was born at Turin. The interval which separates the lives of these two eminent men had seen the labours of Copernicus, Kepler, Napier, Descartes, Pascal, Galileo, Huygens, Leibniz and Newton. Both mathematics and astronomy had flourished increasingly and experimental science had become established, and whereas the work of Regiomontanus had been largely concerned with the writings of the Ancients, that of Lagrange related entirely to the extension and application of the discoveries of his immediate predecessors. His great contemporaries included Euler, the Bernoullis and Laplace.

Born in Italy, but of French descent, Lagrange at the age of nineteen was made a professor of geometry in the Artillery School at Turin and at twenty-five years of age had gained an international reputation. In 1766, through D'Alembert, he was invited by Frederick the Great to fill the place in the Berlin Academy of Sciences left vacant by Euler's removal to St. Petersburg. One of D'Alembert's letters to Frederick ran: "M. de la Grange ne tardera pas à venir remplacer M. Euler ; et j'ose assurer Votre Majesté qu'il le remplacera très bien pour les talents et le travail, et que d'ailleurs, par son caractère et sa conduite, il n'excitera jamais dans l'Académie la moindre division ni le moindre trouble. Je prends la liberté de demander à Votre Majesté ses bontés particulières pour cet homme d'un mérite vraiment rare, et aussi estimable par ses sentiments que par son génie supérieur."

For twenty years Lagrange lived in Berlin, writing some sixty memoirs and compiling his "Mécanique Analytique", published in 1788. On the death of Frederick in 1786, he removed to Paris, was given apartments in the Louvre, and was welcomed into that brilliant circle of men of science which during the Consulate and Empire made Paris the centre of the scientific world. $\mathrm{He}$ died on April 10, 1813, at the age of seventy-seven years, and just as Regiomontanus was buried in the Pantheon at Rome, so Lagrange was interred in the Panthéon in Paris.

Six days before Lagrange was born at Turin, the great engineer James Watt was born at Greenock.
Though he has for long been placed "at the head of all inventors in all ages and nations", Watt wrote when still a young man: "To-day I enter the 35th year of my life and I think I have hardly yet done 35 pence work of good in the world--but I cannot help it." More fitted for the laboratory than the factory, Watt was never a master of men, and his fate might well have been that of many another inventor had he not linked his fortunes with those of Matthew Boulton, whose self-confidence nothing could shake. In 1919, the centenary of Watt's death was worthily commem. orated, and arrangements are now being made to celebrate the bicentenary of his birth. At Greenock the proceedings will extend from January 13 until 19. There will be an exhibition, a pageant, a commemoration service, and on January 17 Lord Rutherford will deliver the Watt Lecture. There will be other lectures at Birmingham and in London, and on Sunday, January 19, representatives of the engineering institutions will attend Evensong in Westminster Abbey, and at the close of the service wreaths will be placed on Chantrey's monument to Watt in St. Paul's Chapel. A memorial exhibition was opened at the Science Museum, South Kensington, on December 20 and will remain open until April 19. Other commemorations are being held in the United States, Germany and Japan.

Of no less interest than the lives of Lagrange and Watt is that of André-Marie Ampère, who died on June 10, 1836, a hundred years ago, and whose centenary will be celebrated by an exhibition at Lyons. The fact that his name, like those of Watt, Ohm and Volta, is familiar throughout the civilised world through being given to one of the electrical units by a later generation of men of science, is but a tribute to the high esteem in which his memory is held. He has indeed been referred to as the "Newton of Electricity". The son of a magistrate of Lyons who fell on the scaffold on November 25, 1793, Ampère was born at the village of Polémieux. $\mathrm{He}$ was precocious and studious far beyond his years, and at twelve years of age he was asking for the works of Bernoulli and Euler, and at eighteen read the "Mécanique Analytique". Poetry, history and chemistry were all read with the same eagerness. At twenty-one he met the charming Julie Carron, to whom he was married three years later, and at twenty-five he was made professor of physics and ehemistry at the Central School at Bourg, the birthplace of Lalande, who with Delambre was afterwards to recognise Ampère's genius and further his promotion. Transferred in $\mathbf{1 8 0 4}$ to Lyons, he was a year or so later assistant professor of analysis at the Ecole Polytechnique, and in 1814 was made a member of the Paris Academy of Sciences. He also 
held the chair of experimental physics in the Collège de France. It was the repetition of Grsted's experiment at the Academy that led to Ampere's work on electro-dynamics which made him famous. He died at Marseilles, and was buried there, but to-day he rests in the Cimetière de Montmartre in Paris.

The years 1736 and 1836 recall many besides Lagrange, Watt and Ampère who left their mark on the progress of science. In February 1736 Stephen Gray died in the seclusion of the Charterhouse, where for years he had assiduously devoted himself to electricity, his experiments on which led the Royal Society to grant him the first awards made under the will of Sir Godfrey Copley. A few months later the German instrument-maker of Amsterdam, Gabriel Fahrenheit, died at the age of fifty years. Fahrenheit made experiments on the boiling points of liquids, brought into general use the mercurial thermometer and in 1724 devised his thermometer scale, one of the three, out of the many used in the eighteenth century, which has survived.

The day before Fahrenheit died, the ill-fated French astronomer Jean Sylvain Bailly was born in Paris (Sept. 15, 1736). Gifted in many ways, Bailly was both president of the National Assembly and Mayor of Paris in 1789, but he lost his popularity over the affair on the Champ des Mars on July 17, 1791, and two years later perished miserably beneath the guillotine. Two other French men of science born in 1736 were Charles Augustin de Coulomb (1736-1806), known for his experiments on friction, his invention of the torsion balance and his investigation on electrical and magnetical attraction, and Jean Baptiste Louis Romé de l'Isle (1736-1790), an artillery officer who became distinguished for his researches in mineralogy and crystallography.

The year 1736 also saw the birth in Great Britain of Francis Egerton, third Duke of Bridgewater (1736-1803), the monument to whom at Ashridge, now the property of the National Trust, bears an inscription stating that by "devoting the energies of his mind to the accomplishment of the most splendid works of inland navigation" he "opened a new field of national industry and rendered the most important services to the commercial interests of this country".

It is but natural that centenaries should be more numerous than bicentenaries, and to give a complete list of men of science of note who either died or were born in 1836 would take much space. A few brief notes must therefore suffice. A contemporary of Ampère's at the Ecole Polytechnique who passed away in 1836 was Louis Marie Henri Navier (1785-1836), a distinguished officer of the Corps des Ponts et Chaussées, known for his work on suspension bridges and his investigations on elasticity. In Great Britain, 1836 saw the death of William Henry (1774-1836), the Manchester chemist who was Copley medallist in 1808; of John Loudon McAdam (1756-1836), who was voted $£ 10,000$ by the Government for his improvements in road-making, and of John Pond (1767-1836), the amateur astronomer who became the successor of Maskelyne and the predecessor of Airy at the Royal Observatory, Greenwich. During Pond's period of office, wrote Airy, "astronomy considered as an accurate representation of the state of the heavens in the most material points has acquired a certainty and an extent which it never had before".

Turning finally to the list of those born in 1836, physics is represented by Emilio Villari (18361904), a foreign member of the Royal Society and the president of the Academy of the Lincei, and by William Grylls Adams (1836-1915), at one time president of the Physical Society and of the Institution of Electrical Engineers ; meteorology by Niels Heinrik Hoffmeyer (1836-1884), the first director of the Danish Government Meteorological Institute ; chemistry by Charles Graham (18361909), professor of chemical technology at University College, London; geodesy by Major-General Sir Charles Wilson (1836-1905), the directorgeneral of the Ordnance Survey ; and engineering by Sir John Wolfe-Barry (1836-1918), the builder of the Tower Bridge and the virtual founder of the British Standards Institution. Mineralogy and geology are represented by Harry Rosenbusch (1836-1914), of Heidelberg; Gustav Tschermak (1836-1927), of Vienna ; and Frederick Wollaston Hutton (1836-1905), one of the pioneers of geology in New Zealand; while among the astronomers born in 1836 were George Washington Hough (1836-1909) and Truman Henry Safford (18361901), both graduates of Harvard, both connected with the Chicago Observatory and both associates of the Royal Astronomical Society, and also Henry Chamberlain Russell (1836-1907), who organised the meteorological service of Australia and was director of Sydney Observatory.

Lastly, we recall the birth on May 17, 1836, of Sir Norman Lockyer, of whom it is said on the memorial tablet to him at the Norman Lockyer Observatory, Salcombe Hill, Sidmouth, that he was a pioneer in astronomical physics, the discoverer of helium in the sun, founder of the British Science Guild and the founder and editor of Nature, 1869-1919. His death took place at Sidmouth on August 16, 1920, less than a year after the publication of the Jubilee number of this journal, in which M. Deslandres had referred to him as "one of the greatest astronomers of all time." 